\title{
Sensation Seeking and Locus of Control in University Students in the Context of Regular Exercise Participation and Gender
}

\author{
Ali Tekin*, Gülcan Tekin, Melih Çalışır \\ Physical Education and Sports School, Bitlis Eren University, Turkey
}

Copyright $\mathrm{C} 2017$ by authors, all rights reserved. Authors agree that this article remains permanently open access under the terms of the Creative Commons Attribution License 4.0 International License

\begin{abstract}
The aim of this study is to determine the locus of control (LC) and sensation seeking (SS) levels of university female students according to regular exercise participation (REP) and gender (G). This descriptive study was initiated in 2016 and finished in 2017. A total of 623 students, 306 females and 317 males, from different academic departments and universities in Turkey participated in the study. Sensation Seeking and Internal-External Locus of Control (IELC) Scales were used as data collecting materials. The independent t-test was performed in the analysis of the data. The meaning level was accepted as $\mathrm{p}<0.05$ and confidence interval was $95 \%$. SS level of the male is higher than the female $(t=-4,091$, $\mathrm{p}=, 000<0.05)$ and the female have higher level of LC than the male $(\mathrm{t}=4,418, \mathrm{p}=, 000<0.05)$. REP was a critical factor for SS $(\mathrm{t}=6,580, \mathrm{p}=, 000<0.05)$ and $\mathrm{LC} \mathrm{t}=-2,584$, $\mathrm{p}=, 010<0.05)$. There was no difference between female REPG and NREPG for LC $(\mathrm{t}=-1,012, \mathrm{p}=, 312>0.05)$ but SS $(\mathrm{t}=11,331, \mathrm{p}=, 000<0.05)$. Additionally; there was no difference between male REP and non-REP groups for SS $(\mathrm{t}=1,027, \mathrm{p}=, 305>0.05)$ but LC $(\mathrm{t}=-4,133, \mathrm{p}=, 000<0.05)$. Further researches are a need to approve the result of this study.
\end{abstract}

Keywords Sensation Seeking, Locus of Control, Regular Exercise

\section{Introduction}

The concept of locus of control (LC) is based on Rotter's theory of social learning [1]. According to Rotter [2], some people have internal locus of control (ILC) while some have external one (ELC). ILC people believe that they can change their environment for their own benefit while those who are ELC think that they are under the control of the environment. ILC people perform better because they think that the events that develop in their lives are due to their qualities. However, ELC people, when they fail, explains it being unlucky as they think that the events around are out of their control or they comment on the successes of others, their luck, or the simplicity of the task given [3]. Therefore, LC refers to an individual's perception about the underlying main causes of events in his/her life.

Sensation seeking (SS) was expressed as "experiencing a number of new, diverse, complex experiences and facing up to physical, social, legal and financial risks for these experiences," and it was stated that the individual cannot be satisfied if the level of arousal that the experience creates in the individual is insufficient [4]. Dimensions of SS behavior are thrill and adventure seeking (TAS), experience seeking (ES), disinhibition (DIS), and boredom susceptibility (BS). Individuals in TAS dimension are characterized by the desire to participate in unusual activities for seeking of sensational adventure [5]. They have a high desire for thrill and adventure so they are eager to participate in physical activities involving risk [6,7] and extreme conditions requiring speed and danger [8]. Those who are concentrated in the dimension of ES are seeking new places where uncommon experiences, travels, feelings and thoughts exists [9]. Music, art, travel, discovery of new places, and social partnerships offer extensive opportunities for these kinds of people [10]. The individuals of the DIS dimension tend to participate in unpressured social activities [11] or ignore social barriers [9]. Such individuals are subject to getting alcohol, gambling and sexual behavior [12]. The people of BS dimension do not like ordinary, monotonous, repetitive and constant states [9] as they are prone to boredom [6-8).

University years, a transition period between adolescence and adulthood, encourage individuals to taste new experiences [13]. It seems that the university students in this period frequently expose some risky attitudes and behaviors [14]. Looking at studies on SS, sports and traffic accidents resulting in injury or death, it is seen that young people aged 16-24, especially men, are more concerned with taking 
the highest risks [15]. In addition, it was suggested that gender is a variable that affects risk taking behaviors and that males have a higher level of SS than females [16, 17]. In the study of college students' SS level, regardless of sport participation; males were higher than females and controlling gender; athletes were higher than non-athletes [18].

When the subject is LC, in one study it is revealed that male and female athletes have different LC scores; female ones have higher level of ILC than men. Additionally, there is a meaningful and positive relationship between physical strength, fitness perceptions and LC [19]. According to the result of another study, there is a relationship between locus of control and the leisure activities of university students. The students who have ILC spend more time on sporting activities than those who have ELC [20]. Thus, the aim of this research is to determine the LC and SS level of university students according to regular exercise participation (REP) and gender (G) variables. The following questions will be tried to be answered in line with the purpose of the research:

1. Is there any significant difference between the mean SS and LC score of male and female groups in terms of gender?

2. Is there any significant difference between the mean SS and LC score of male and female groups in terms of REP?

3. Is there any significant difference in the mean SS and LC score in male group for gender?

4. Is there any significant difference in the mean SS and LC score in male group for REP?

\section{Materials and Methods}

This descriptive study was initiated in 2016 and finished in 2017. A total of 623 students, 306 women and 317 men, from different academic departments and universities in Turkey participated in the study. The inclusion criteria were to be 18 years of age or older and voluntary. REP was determined by self-report. Those who declared that they exercise 30-45 minutes at least three days a week in a moderate level were considered as regular exercisers. Data gathering material were Sensation Seeking and Internal-External Locus of Control Scales. The scales applications were made in the form of a plenary session under the supervision of researchers. Before applications, the researchers explained the purpose of the study and reminded the principle of voluntary participation to the students.

\section{Sensation Seeking Scale (SSS):}

SSS, developed by Zuckerman [21], is a widely used scale to determine SS. The adaptation study of SSS to Turkish population (validity and reliability) was performed (total internal consistency coefficient 0.82 ) by Öngen [22]. SSS consists of a total of 40 items and 4 sub-dimensions, each of which contains 10 items with A and B options. TAS sub-dimension reflects the desire to do exciting unusual activities with speed and dangerous behaviors (items: 3, 11, $16,17,20,21,23,28,38$, and 40). ES dimension includes an unusual way of life, a seeking for new and different experiences, and expressions about an unusual lifestyle (4, 6, $9,10,14,18,19,22,26$, and 37). The DIS dimension includes items that reflect the need to engage in social or sex-related activities by consuming alcohol or similar substances $(1,12,13,25,29,30,32,33,35$, and 36). BS consists of the items $2,5,7,8,15,24,27,31,34$, and 39 which are about routine and boring activities or states that express dislike of monotonous and dull people. The Scores obtained from the scale can range from $0-40$. The scores over 20 mean that the level of SS is higher than average.

\section{Rotter's Internal-External Locus of Control Scale (RIELCS)}

RIELCS was developed by Rotter [22] and adaptation study (reliability and validity) to Turkish population were conducted by Dağ [23]. The scale shows the position of the individuals' control expectations on the internality-externality dimension; it measures the general expectation or belief of an individual on whether the reinforcements are in the control of inner or outer (chance or fortune) forces. The scale consists of 29 forced-choice items (a, and b). Six of them $(1,8,14,19,24$, and 27) are fillers, 23 keyed (score range is 0 to 23 ). The increase in score points to external locus of control. The internal reliability score of the scale was 0.71 . The measurement reliability of its scale was found significant with negative and positive values $(\mathrm{r}=-0.29, \mathrm{p}<0.001 ; \mathrm{r}=0.21, \mathrm{p}<0.001)$ [24].

In the analysis of data obtained from scale applications the independent samples t-test was used by SPSS package program. The independent samples t-test compares the means of two independent groups in order to determine whether there is a statistical evidence that the associated population means are significantly different. The independent samples t-test are parametric tests. Frequency, mean scores, standard deviation, standard error mean, degree of freedom and mean difference were given. The meaning level was accepted as $\mathrm{p}<0.05$ and confidence interval was $95 \%$.

\section{Findings}

As seen in Table 1, the mean SS score of male group is higher than that of female $(t=-4,091, p=, 000<0.05)$ while the mean LC score of male is lower than that of female $(\mathrm{t}=4,418, \mathrm{p}=, 000<0.05)$, meaning that there are significant differences in group comparisons of SS and LC levels in terms of gender. 
Table 1. Result of Group Comparisons according as Gender

\begin{tabular}{|c|c|c|c|c|c|c|c|c|c|}
\hline \multirow{2}{*}{ Variables } & \multirow{2}{*}{ Groups } & \multirow{2}{*}{$\mathrm{n}$} & \multirow{2}{*}{$\overline{\mathrm{X}}$} & \multirow{2}{*}{$\mathrm{sd}$} & \multirow{2}{*}{$\mathrm{se}_{\mathrm{m}}$} & \multicolumn{4}{|c|}{ t-test } \\
\hline & & & & & & $t$ & $\mathrm{df}$ & $\mathrm{md}$ & $p$ \\
\hline \multirow{2}{*}{ BS } & Female & 306 & 7,39 & 1,922 & , 110 & \multirow{2}{*}{$-2,988$} & \multirow{2}{*}{621} & \multirow{2}{*}{,- 412} & \multirow{2}{*}{, $003 *$} \\
\hline & Male & 317 & 7,80 & 1,929 & , 108 & & & & \\
\hline \multirow{2}{*}{ DIS } & Female & 306 & 7,24 & 2,625 & , 150 & \multirow{2}{*}{$-3,454$} & \multirow{2}{*}{621} & \multirow{2}{*}{,- 587} & \multirow{2}{*}{, $001 *$} \\
\hline & Male & 317 & 7,82 & 2,277 &, 127 & & & & \\
\hline \multirow{2}{*}{ ES } & Female & 306 & 6,92 & 2,358 & , 134 & \multirow{2}{*}{$-2,668$} & \multirow{2}{*}{621} & \multirow{2}{*}{,- 646} & \multirow{2}{*}{, $008^{*}$} \\
\hline & Male & 317 & 7,57 & 2,309 & , 129 & & & & \\
\hline \multirow{2}{*}{ TAS } & Female & 306 & 7,08 & 2,143 & , 122 & \multirow{2}{*}{$-3,276$} & \multirow{2}{*}{621} & \multirow{2}{*}{,- 596} & \multirow{2}{*}{, $001 *$} \\
\hline & Male & 317 & 7,67 & 2,390 & , 134 & & & & \\
\hline \multirow{2}{*}{ SS } & Female & 306 & 28,55 & 6,893 & ,394 & \multirow{2}{*}{$-4,091$} & \multirow{2}{*}{621} & \multirow{2}{*}{$-2,318$} & \multirow{2}{*}{, $000 *$} \\
\hline & Male & 317 & 30,87 & 7,237 & ,406 & & & & \\
\hline \multirow{2}{*}{ LC } & Female & 306 & 14,34 & 3,665 & ,209 & \multirow{2}{*}{4,418} & \multirow{2}{*}{621} & \multirow{2}{*}{1,248} & \multirow{2}{*}{, $000 *$} \\
\hline & Male & 317 & 13,10 & 3,387 & , 190 & & & & \\
\hline
\end{tabular}

Table 2. Group Comparisons of Total Participants for REP

\begin{tabular}{|c|c|c|c|c|c|c|c|c|c|}
\hline \multirow{2}{*}{ Variables } & \multirow{2}{*}{ Groups } & \multirow{2}{*}{$\mathrm{n}$} & \multirow{2}{*}{$\bar{X}$} & \multirow{2}{*}{ sd } & \multirow{2}{*}{$\mathrm{se}_{\mathrm{m}}$} & \multicolumn{4}{|c|}{ t-test } \\
\hline & & & & & & $\mathrm{t}$ & $\mathrm{df}$ & $\mathrm{md}$ & $\mathrm{p}$ \\
\hline \multirow{2}{*}{ BS } & REPG & 295 & 8,081 & 1,905 & ,110 & \multirow{2}{*}{5,290} & \multirow{2}{*}{631} & \multirow{2}{*}{1,026} & \multirow{2}{*}{, $000^{*}$} \\
\hline & NREPG & 328 & 7,054 & 2,799 & , 154 & & & & \\
\hline \multirow{2}{*}{ DIS } & REPG & 295 & 7,901 & 1,696 & ,098 & \multirow{2}{*}{6,710} & \multirow{2}{*}{631} & \multirow{2}{*}{1,224} & \multirow{2}{*}{, $000^{*}$} \\
\hline & NREPG & 328 & 6,676 & 2,690 & , 148 & & & & \\
\hline \multirow{2}{*}{ ES } & REPG & 295 & 7,979 & 1,549 & ,090 & \multirow{2}{*}{4,692} & \multirow{2}{*}{631} & \multirow{2}{*}{, 717} & \multirow{2}{*}{, $000^{*}$} \\
\hline & NREPG & 328 & 7,262 & 2,176 & , 120 & & & & \\
\hline \multirow{2}{*}{ TAS } & REPG & 295 & 7,816 & 1,829 & , 106 & \multirow{2}{*}{4,532} & \multirow{2}{*}{631} & \multirow{2}{*}{, 820} & \multirow{2}{*}{, $000^{*}$} \\
\hline & NREPG & 328 & 6,997 & 2,577 & , 142 & & & & \\
\hline \multirow{2}{*}{ SS } & REPG & 295 & 31,661 & 5,166 & ,300 & \multirow{2}{*}{6,580} & \multirow{2}{*}{631} & \multirow{2}{*}{3,657} & \multirow{2}{*}{, $000^{*}$} \\
\hline & NREPG & 328 & 28,003 & 8,194 & ,452 & & & & \\
\hline \multirow{2}{*}{ LC } & REPG & 295 & 13,325 & 3,710 & ,216 & \multirow{2}{*}{$-2,584$} & \multirow{2}{*}{631} & \multirow{2}{*}{,- 738} & \multirow{2}{*}{, $010^{*}$} \\
\hline & NREPG & 328 & 14,064 & 3,423 & , 189 & & & & \\
\hline
\end{tabular}

When Table 2 which shows group comparisons of all participants for REP is examined, it is seen that the mean SS score of REPG is higher than that of NREPG $(t=6,580, p=, 000<0.05)$, whereas REPG's average LC score is lower than that of NREPG $(t=-2,584, p=, 010<0.05)$. These results prove the significant differences between groups for SS and LC.

Table 3. Comparisons of Male Participants according as REP

\begin{tabular}{|c|c|c|c|c|c|c|c|c|c|}
\hline \multirow{2}{*}{ Variables } & \multirow{2}{*}{ Groups } & \multirow{2}{*}{$\mathrm{n}$} & \multirow{2}{*}{$\overline{\mathrm{X}}$} & \multirow{2}{*}{$\mathrm{sd}$} & \multirow{2}{*}{$\mathrm{se}_{\mathrm{m}}$} & \multicolumn{4}{|c|}{ t-test } \\
\hline & & & & & & $\mathrm{t}$ & df & $\mathrm{md}$ & $\mathrm{p}$ \\
\hline \multirow{2}{*}{ BS } & REPG & 122 & 8,073 & 2,013 &, 182 & \multirow{2}{*}{1,513} & \multirow{2}{*}{315} & \multirow{2}{*}{,396 } & \multirow{2}{*}{,131 } \\
\hline & NREPG & 195 & 7,676 & 2,420 & , 173 & & & & \\
\hline \multirow{2}{*}{ DIS } & REPG & 122 & 7,901 & 2,022 & ,183 & \multirow{2}{*}{2,007} & \multirow{2}{*}{315} & \multirow{2}{*}{, 532} & \multirow{2}{*}{,046* } \\
\hline & NREPG & 195 & 7,369 & 2,455 & , 175 & & & & \\
\hline \multirow{2}{*}{ ES } & REPG & 122 & 7,704 & 1,879 &, 170 & \multirow{2}{*}{,- 726} & \multirow{2}{*}{315} & \multirow{2}{*}{,- 161} & \multirow{2}{*}{,468 } \\
\hline & NREPG & 195 & 7,866 & 1,961 & , 140 & & & & \\
\hline \multirow{2}{*}{ TAS } & REPG & 122 & 7,795 & 2,207 & , 199 & \multirow{2}{*}{,688 } & \multirow{2}{*}{315} & \multirow{2}{*}{,189 } & \multirow{2}{*}{,492 } \\
\hline & NREPG & 195 & 7,605 & 2,500 & , 179 & & & & \\
\hline \multirow{2}{*}{ SS } & REPG & 122 & 31,401 & 6,592 & ,596 & \multirow{2}{*}{1,027} & \multirow{2}{*}{315} & \multirow{2}{*}{,858 } & \multirow{2}{*}{,305 } \\
\hline & NREPG & 195 & 30,543 & 7,610 & ,545 & & & & \\
\hline \multirow{2}{*}{$\mathrm{LC}$} & REPG & 122 & 12,131 & 3,044 & ,275 & \multirow{2}{*}{$-4,133$} & \multirow{2}{*}{315} & \multirow{2}{*}{$-1,576$} & \multirow{2}{*}{, $000 *$} \\
\hline & NREPG & 195 & 13,707 & 3,456 & 247 & & & & \\
\hline
\end{tabular}

The result of group comparisons for the variable of REP in males is an evidence that there is not any difference for SS $(\mathrm{t}=1,027, \mathrm{p}=, 305>0.05)$ but for $\mathrm{LC}(\mathrm{t}=-4,133, \mathrm{p}=, 000<0.05)$ between REPG and NREPG groups. 
Table 4. Comparisons of Female Participants according as REP

\begin{tabular}{|c|c|c|c|c|c|c|c|c|c|}
\hline \multirow{2}{*}{ Variables } & \multirow{2}{*}{ Groups } & \multirow{2}{*}{$\mathrm{n}$} & \multirow{2}{*}{$\overline{\mathrm{X}}$} & \multirow{2}{*}{ sd } & \multirow{2}{*}{$\mathrm{se}_{\mathrm{m}}$} & \multicolumn{4}{|c|}{ t-test } \\
\hline & & & & & & $\mathrm{t}$ & $\mathrm{df}$ & $\mathrm{md}$ & $\mathrm{p}$ \\
\hline \multirow{2}{*}{ BS } & REPG & 173 & 8,086 & 1,832 & ,139 & \multirow{2}{*}{6,893} & \multirow{2}{*}{304} & \multirow{2}{*}{1,943} & \multirow{2}{*}{, $000^{*}$} \\
\hline & NREPG & 133 & 6,142 & 3,065 & ,265 & & & & \\
\hline \multirow{2}{*}{ DIS } & REPG & 173 & 7,901 & 1,429 & , 108 & \multirow{2}{*}{9,325} & \multirow{2}{*}{304} & \multirow{2}{*}{2,240} & \multirow{2}{*}{, $000^{*}$} \\
\hline & NREPG & 133 & 5,661 & 2,707 & ,234 & & & & \\
\hline \multirow{2}{*}{ ES } & REPG & 173 & 8,173 & 1,236 & ,093 & \multirow{2}{*}{9,109} & \multirow{2}{*}{304} & \multirow{2}{*}{1,797} & \multirow{2}{*}{, $000^{*}$} \\
\hline & NREPG & 133 & 6,375 & 2,179 & , 189 & & & & \\
\hline \multirow{2}{*}{ TAS } & REPG & 173 & 7,832 & 1,513 & ,115 & \multirow{2}{*}{7,612} & \multirow{2}{*}{304} & \multirow{2}{*}{1,727} & \multirow{2}{*}{, $000^{*}$} \\
\hline & NREPG & 133 & 6,105 & 2,434 & ,211 & & & & \\
\hline \multirow{2}{*}{ SS } & REPG & 173 & 31,843 & 3,869 & ,294 & \multirow{2}{*}{11,331} & \multirow{2}{*}{304} & \multirow{2}{*}{7,565} & \multirow{2}{*}{, $000^{*}$} \\
\hline & NREPG & 133 & 24,278 & 7,596 & 658 & & & & \\
\hline \multirow{2}{*}{$\mathrm{LC}$} & REPG & 173 & 14,167 & 3,910 & ,297 & \multirow{2}{*}{$-1,012$} & \multirow{2}{*}{304} & \multirow{2}{*}{,- 418} & \multirow{2}{*}{, 312} \\
\hline & NREPG & 133 & 14,586 & 3,319 & 287 & & & & \\
\hline
\end{tabular}

The result of group comparisons for the variable of REP in females exposed that there is not any difference between REPG and NREPG for LC $(t=-1,012, p=312>0.05)$ whereas, significant differences is observed in $\mathrm{SS}(\mathrm{t}=11,331$, $\mathrm{p}=, 000<0.05$ ).

\section{Conclusions}

In this part of the study, the analysis results were evaluated according to the current literature.

\section{Male-Female Comparisons for SS and LC:}

In the comparison of male and female groups for SS, we found that the mean SS scores of male group were higher than those of female $(t=-4,091, p=, 000<0.05$. In Turkey, girls are in many ways more disadvantaged than boys because they have to deal more with barriers in areas such as education, leisure, information and gathering full participation. All these conditions lead to serious and sometimes dramatic consequences for girls in Turkey. Especially girls cannot clearly reveal their social identities for reasons such as conservative social norms, domestic responsibilities or social adjustment problems. If we ignore the biological factors, one of the possible reasons why males' level of SS is higher than that of females may be the substantial disadvantages that exist in Turkey for girls. Girls may have denied both practice and perceptual sense of SS activities due to family and social pressures or lack of tolerance. This result of our study is consistent with the results of the studies which concluded that males are higher than women in SS level [25-27]. In a study interests and preferences of SS, Buswell and James [28] examined 332 students of a university who were majoring in health, physical education, recreation and elementary education; the results referred to significantly higher scores for males in SS.

And it is also found that the mean LC scores of male group lower than those of female $(\mathrm{t}=4,418, \mathrm{p}=, 000<0.05)$. As stated before, internal locus of control is simply expressed as the attribution to the external factors as the causes of success and failure of an individual. It is not surprising that females living in these aforesaid social conditions have more internal locus of control than males. While males can act more independently to participate in all kind of activities such as cultural, recreational, sports, and social, females try to move away from the problem by obeying external orders and prohibitions (expectation from the family, social environment and society) against criticisms that may arise. It is normal in this situation to make females more dependent on others and the environment. When the studies on the control locus of university students are examined, there are also research results that do not support as much as the studies supporting the results obtained in this research. On one hand, Malki [29], Akbulut [30] and Terzi [31] found in the samples of students from different Turkish universities that male are more internally locus of control than males, on the other hand, there were no differences in the locus of control scores between male and female university students in the studies of Yagısan [32], Durna and Sentürk [20], Basol and Turkoglu, [33], Saracaloğlu and Yılmaz [34], Saracaloğlu, Serin and Bozkurt [35] and Cengil [36].

\section{SS and LC according to Regular Sports Participation}

We also found that regular exercise participation was a critical factor for the sample of the study as the participants of REP group exposed have higher level of SS $(t=6,580$, $p=, 000<0.05)$ and lower level of LC than those of non-REP $(\mathrm{t}=-2,584, \mathrm{p}=, 010<0.05)$. In-group comparisons for female, there were no difference between REP and non-REP for LC $(\mathrm{t}=-1,012, \mathrm{p}=, 312>0.05)$ whereas, significant differences 
were observed in SS $(t=11,331, \mathrm{p}=, 000<0.05)$. Additionally, in-group comparisons for male, there was no difference between REP and non-REP groups for SS $(t=1,027$, $\mathrm{p}=, 305>0.05)$ but $\mathrm{LC}(\mathrm{t}=-4,133, \mathrm{p}=, 000<0.05)$. Similar results were in the study of Mokhtari et al. [37]; athletes scored higher in SS than non-athletes. Schroth [38] determined that male athletes scored higher in SS than male non-athletes; moreover, the SS scores of male contact sport athletes were higher than male non-contact sport athletes. The same results were also for female; female athletes had significantly higher SS scores than female non-athletes. O'Sullivan et al. [39] got discordant results to ours as male football players scored lower than the general university male population on SS. Malkin and Rabinowitz [40] concluded that high sensation seekers have more participation in high-risk activities and there are some cultural and economic differences between high and low sensation seekers. In some researches $[41,42]$ it is exposed that high-risk sports participants have higher levels of SS and openness to experience than those of low-risk sports. But some findings were discordant to ours $[43,44]$. In this study a significant difference was found between LC of male and female university students; the female had higher scores of LC. There are many researches that support this result [45-47]. But some contradictory results are also available [48-51]. Physical activity is related to LC [52]. Athletes have been found to possess a greater internal LC due to participation in competitive situations [53]. Athletes also have more control on their life and see themselves the reason for their successes and defeats. There were meaningful differences observed in LC levels of athlete and non-athlete girl students [54].

The study which aimed to determine the LC and SS level of university students according to regular exercise participation (REP) and gender (G) concluded that males are more internally controlled than female, and the male have higher level of SS when compared to the female, REP is also effective on SS and LC. The literature supports most of the results, but not all. So, further research on the same issue should be conducted to reach certain results.

\section{REFERENCES}

[1] J.B. Rotter. Social learning and clinical psychology, Englewood Cliffs, New Jersey: Prentice-Hall, 1954.

[2] J.B. Rotter. Generalized expectancies for internal versus external control of reinforcements, Psychological Monographs, General and Applied, 80, 1-28, 1966.

[3] A.R. Ozolins, U. Stenström. Validation of health locus of control patterns in Swedish adolescents, Adolescence, 38(152), 651-657, 2003.

[4] M. Zuckerman, Sensation seeking and risky behavior, Washington, DC: American Psychological Association, 2007.

[5] J.B. Hittner, R. Swickert. Sensation seeking and alcohol use: meta analytic review. Addictive Behaviour, 31(8), 1383-1401, 2006.

[6] G. Fuchs. Low versus high sensation-seeking tourists: a study of backpackers' experience risk perception, International Journal of Tourism Research, 15(1), 81-92, 2013.

[7] Pizam, A. Reichel, N. Uriely. Sensation seeking and tourist behavior. Journal of Hospitality and Leisure Marketing. 9(3-4), 17-33, 2001.

[8] W. Wang, Y. Wu, Z. Peng, S.W. Lu, L. Yu, G.P. Wang, X.M. Fu, Y.H. Wang. Test of sensation seeking in a Chinese sample, Personality and Individual Differences, 28(1), 169-179, 2000.

[9] P. Eachus. Using the brief sensation seeking scale (bsss) to predict holiday preferences, Personality and Individual Differences, 36(1), 141-153, 2004.

[10] E.S.T. Wang, L.S.L. Chen, J.Y.C, Lin, M.C.H. Wang. The relationship between leisure satisfaction and life satisfaction of adolescents concerning online games, Adolescence, 43(169), 177-184, 2008.

[11] N. Lapsekili, Ö. Uzun, M. Ak. Obsesif kompulsif bozukluk olgularında heyecan arama davranışı, Klinik Psikiyatri, 13(4), 170-176, 2010.

[12] K.Y. Şimşek. Ekstrem spor tüketim güdülerinin Türkiye'deki ekstrem spor katılımcılarının algıladıkları değere, algıladıkları tatmine ve davranışsal niyetlere etkisi. (Doktora Tezi). Eskişehir, Anadolu Üniversitesi Sağlık Bilimleri Enstitüsü, 2011.

[13] J. Dworkin. Risk taking as developmentally appropriate experimentation for college students, Journal of Adolescent Research, 20 (2), 219-241, 2005.

[14] Z.F. Temel, A. Aksoy. Ergen ve gelişimi, yetişkinliğe ilk adım, 1.basım, 2001.

[15] R.M. Trimpop, The Psychology of Risk Taking Behavior. Amsterdam: Elsevier Science, 1994.

[16] Ö.E. Gülgez. Lise öğrencilerinin olumsuz risk alma davranışlarının psikolojik belirtiler, yaş ve cinsiyet değişkenleri açısından incelenmesi. Yayınlanmamış Yüksek Lisans Tezi. Gazi Üniversitesi, Eğitim Bilimleri Enstitüsü, Eğitimde Psikolojik Hizmetler Anabilim Dalı, 2007.

[17] E. Gullone, S. Moore. Adolescent risk-taking and the five factor model of personality. Journal of Adolescence, 23 (4), 393-407, 2000.

[18] M. K. Hartman, H.E. Rawson. Differences in and correlates of sensation seeking in male and female athletes and nonathletes, Personality and Individual Differences, 13(7), 807-812, 1992.

[19] C. Koca, F. H. Aşçı, Z. B. Oyar. Elit sporcuların denetim odağı ve fiziksel benlik algısının cinsiyete, yapılan spor branşına ve spor deneyimine göre karşılaştırılması, Gazi Beden Eğitimi ve Spor Bilimleri Dergisi, 8(4), 3-10, 2003.

[20] U. Durna, F.K. Şentürk, Üniversite öğrencilerinin sosyal faaliyetlerinin denetim odağı düzeyi açısından incelenmesi: Bir devlet üniversitesi örneği. Süleyman Demirel Üniversitesi İktisadi ve İdari Bilimler Fakültesi Dergisi, 17(2), 187-202, 2012.

[21] M. Zuckerman. Behavioral expressions and biosocial bases of 
sensation seeking. New York: Cambridge University Press, 1994.

[22] D. Öngen. The relationship between sensation seeking and gender role orientation among Turkish university students, Sex Roles, 57(1-2), 111-118, 2007.

[23] İ. Dağ. Rotter'in iç-dış kontrol odağı ölçeğinin (RIDDKÖ) Üniversite Öğrencileri için güvenirliği ve geçerliği, Psikoloji Dergisi, 7(26), 10-16, 1991.

[24] A.D. Çelik, N. Telman. Endüstri/Örgüt Psikolojisi Alanında Kullanılan Ölçekler El Kitabı, Nobel Yayınları, 63-74, 2013.

[25] G. Hirschberger, V. Florian, M. Mikulincer, J. Goldenber, T. Pyszczynski Gender differences in the willingness to engage in risky behavior: A terror management perspective. Death Studies, 26(2), 117-141, 2002.

[26] Butkovic, D. Bratko. Generation and sex differences in sensation seeking: Results of the family study. Percept Motor Skill, 97(3), 965-970, 2003.

[27] Hromatko. Butkovic. A. Sensation seeking and spatial ability in athletes: an evolutionary account, Journal of Human Kinetics, 21(2), 5-13, 2009.

[28] D.J. Buswell, G. James. Sensation seeking in Texas HPER and elementary education college students. [Abstract]. Faculty Publications, Paper 17, 2006.

[29] R. Malki. Davranışlarda iç-dış kontrol odağı ile ruh sağlığı arasındaki ilişkinin incelenmesi. Yayınlanmamış yüksek lisans tezi, Ege Üniversitesi, İzmir, 1998.

[30] A.R. Terzi. Denetim odağı ve örgütsel vatandaşlık davranışı ilişkisi: Üniversite öğrencileri üzerinde bir araştırma. Eğitim ve Bilim, 36(162), 3-15, 2011.

[31] E. Akbulut. Müzik Eğitimi Anabilim Dalı Öğrencilerinin Denetim Odaklarına İlişkin Algıları, GÜ Gazi Eğitim Fakültesi Dergisi, 26 (3), 171-180, 2006.

[32] N. Yağışan. Müzik bölümü öğrencilerinin benlik imgeleri ve denetim odaklarının incelenmesi, Erciyes Üniversitesi Sosyal Bilimler Enstitüsü Dergisi, 1(22), 243-262, 2007.

[33] G. Başol, E. Türkoğlu. Sınıf öğretmeni adaylarının düşünme stilleri ile kontrol odağı durumları arasındaki ilișki. Uluslararası İnsan Bilimleri Dergisi, 6(1), 732-757, 2009.

[34] A.S. Saraçaloğlu, S. Yılmaz. Öğretmen adaylarının eleştirel düşünme tutumları ile denetim odaklarının incelenmesi, İlköğretim Online, 10(2), 468-478, 2011.

[35] A.S. Saraçaloğlu, O. Serin, N. Bozkurt. Eğitim bilimleri enstitüsü öğrencilerinin problem çözme ve denetim odağı düzeylerinin bazı değişkenler açısından incelenmesi, Buca Eğitim Fakültesi Dergisi Eğitimde Bilime Katk1 Lisansüstü Eğitim Sempozyumu Özel Sayı 1, 17, 237-242, 2005.

[36] M. Cengil. Gazi Üniversitesi Çorum İlahiyat Fakültesi öğrencilerinin denetim odaklarının çeşitli değişkenlere göre incelenmesi. Hitit Üniversitesi İlahiyat Fakültesi Dergisi, 3(5), 65-88, 2004.

[37] R.A. Mokhtari, F. Keavanloo, M. Seyedahmadi. The Comparison of Sensation-seeking in students. International Research Journal of Applied and Basic Sciences, Vol, 6(4), 496-498, 2013.

[38] M.L. Schroth. A comparison of sensation seeking among different groups of athletes and nonathletes, Personality and Individual Differences, 18(2), 219-222, 1995.

[39] D.M. O'Sullivan, M. Zuckerman, M. Kraft. Personality characteristics of male and female participants in team sports. Personality and individual differences, 25(1), 119-128, 1998.

[40] M.J. Malkin, E. Rabinowitz. Sensation seeking and high-risk recreation-research report, Parks \& Recreation, 33(2), 30-42, 1998.

[41] C.R. Diehm. Armatas Surfing: an avenue for socially acceptable risk-taking, satisfying needs for sensation seeking and experience seeking, Personality and Individual Differences, 36(3), 663-679, 2004

[42] M. Guszkowska, A. Bołdak. Sensation seeking in males involved in recreational high risk sports, Biology of Sport, 27(3),157-162, 2010

[43] D. Lafollie, C. Le Scanff, P. Fontayne. French adaptation of the Risk and Excitement Inventory (REI). Canadian Journal of Behavioral Science, 40(2), 113-119, 2008.

[44] D. J. Rhea, S. Martin. Personality trait differences of traditional sport athletes, bullriders, and other alternative sport athletes. International Journal of Sports Science \& Coaching, 5(1), 75-85. 2010.

[45] [45] Ghasemzadeh, M. Saadat. Locus of control in Iranian university Student and its relationship with academic achivement. Procedia -Social and Behavioral Sciences, 30, 2491-2496, 2011

[46] I.H. Zaidi, M.N. Mohsin. Locus of control in graduation students. International Journal of Psychological Research, 6(1), 15-20, 2013

[47] M.L. Wehmeyer. Gender differences in locus of control scores for students with learning disabilities. Percept Mot Skills, 77(2), 359-366, 1993.

[48] M. Rastegar, N. Heidari, The relationship between locus of control, test anxiety, and religious orientation among Iranian EFL students, Scientific Research, 3(1), 73-78, 2013.

[49] M. Meghan. Satisfaction in adult romantic relationships after parental divorce: the role of locus of control. Theses, Dissertations, and Projects, Smith College, Paper 617, 2012.

[50] D. Clarke. Neuroticism: moderator or mediator in the relation between locus of control and depression, Journal Personality and Individual Differences 37(2), 245-258, 2004.

[51] A.R. Naik. A study on locus of control among college students of Gulbarga city. The International Journal of Indian Psychology, 2(4), 47-54, 2015.

[52] E.M. Parsons, N.E. Betz. The relationship of participation in sports and physical activity to body objectification, instrumentality, and locus of control among young women. Psychology of Women Quarterly, 25(3), 209-222, 2001.

[53] A.F. Morris, P. Vaccaro, D.H. Clarke. Psychological characteristics of age-group competitive swimmers. Perceptual and Motor Skills, 48(3), 1265-1266, 1979.

[54] L. Samaei, Z.N. Ramezani, A.S.H. Semnani. Relationship between locus of control (internal-external) and a feeling of the loneliness between athletic and non athletic girls. European Journal of Experimental Biology, 2 (5), 1862-1867, 2012. 